\title{
Magnesium isotopic composition of Variscan subduction-related plutonic rocks and its significance for the origin of ultrapotassic magmas (Moldanubian Zone of Bohemian Massif)
}

VOJTECH JANOUSEK ${ }^{1}$, YULIA KOCHERGINA ${ }^{1}$, ALEXANDRE ANDRONIKOV ${ }^{1}$ AND VLADIMIR $\mathrm{KUSBACH}^{2}$

${ }^{1}$ Czech Geological Survey

${ }^{2}$ Institute of Geophysics, Czech Academy of Sciences

Presenting Author: vojtech.janousek@geology.cz

Variscan Orogeny in the Bohemian Massif was likely driven by oceanic subduction passing to subduction/relamination of the Saxothuringian continental crust [1]. This resulted in extensive magmatism ranging from (1) $\sim 354$ Ma normal calc-alkaline (CA), through (2) 346 Ma K-rich calc-alkaline (HKCA) to (3) $\sim 340-335$ Ma (ultra-)potassic (UK) [2-3]. The $\mathrm{Sr}-\mathrm{Nd}$ isotopic compositions of mantle-derived members evolved from CHURlike $\left({ }^{87} \mathrm{Sr}^{86} \mathrm{Sr}_{354} \sim 0.705, \varepsilon^{354}{ }_{\mathrm{Nd}} \sim+1\right.$; CA), through slightly $\left({ }^{87} \mathrm{Sr} /{ }^{86} \mathrm{Sr}_{346} \sim 0.707, \varepsilon \varepsilon^{346}{ }_{\mathrm{Nd}}=-3\right.$ to -4 ; HKCA) to strongly enriched $\left({ }^{87} \mathrm{Sr}^{86} \mathrm{Sr}_{337}>0.7128, \varepsilon^{337}{ }_{\mathrm{Nd}}<-7.5\right.$; UK) [3-4]. The ultrapotassic primary melts came from harzburgitic mantle contaminated by deeply subducted mature crustal material and/or metasomatized by (U)HP melts/fluids derived therefrom [4-7].

The three suites yield heterogeneous $\delta^{26} \mathrm{Mg}$ values $(-0.12 \%$ to $-0.53 \%$ ). Surprisingly, the most magnesian samples, taken as proxies for mantle-derived sources, all fall within the range of the local orogenic mantle peridotites $(-0.33 \%$ to -0.29$)$ or above, close to the global mantle average $(-0.25 \%$ [8]). Thus the $\delta^{26} \mathrm{Mg}$ of the metasomatized mantle was buffered by the harzburgitic mantle end-member, and/or the crustal contaminant was not very contrasting in $\delta^{26} \mathrm{Mg}$. This implies insignificant role for $\mathrm{Mg}$ in melts/fluids derived from subducted clastic or carbonate sediments.

However, the inventory of incompatible elements and related isotopic systems $(\mathrm{Sr}-\mathrm{Nd}-\mathrm{Pb})$ in the hybrid UK suite (high mg\#, transition metal and $\mathrm{Cs}, \mathrm{Rb}, \mathrm{K}, \mathrm{Th}, \mathrm{U}, \mathrm{Pb}, \mathrm{Li}$ contents; low $\mathrm{Nb}$, $\mathrm{Ta}$ and Ti contents) was swamped by the crustal signal. This confirms the hypothesis that the within-mantle contaminant and source of metasomatic melts/fluids was mainly Mg-poor, felsic igneous material of Saxothuringian provenance [4, 7].

Supported by GACR project 18-24378S to VJ.

[1] Schulmann et al. (2014), Geology 42, 275-278.

[2] Žák et al. (2014), Geol. Soc. London Spec. Pub. 405, 169196.

[3] Janoušek et al. (2000), J. Petrol. 41, 511-543.

[4] Janoušek et al. (2020), Int. J. Earth Sci. 109, 1767-1810.

[5] Becker et al. (1999), J. Petrol. 41, 315-338.

[6] Janoušek \& Holub (2007), Proc. Geol. Assoc. 118, 75-86.

[7] Janoušek et al. (2019), Lithos 342-343, 239-262.

[8] Teng et al. (2010), Geochim. Cosmochim. Acta 74, 4150 